Supporting Information

\title{
Effect of an Electrospray-Generated Ionomer
}

\section{Morphology on Polymer Electrolyte Fuel Cell \\ Performance}

Seonghun Cho, Kayoko Tamoto, Makoto Uchida*

Fuel Cell Nanomaterials Center, University of Yamanashi, 4-4-37 Takeda, Kofu, Yamanashi 4008510, Japan

Corresponding author: uchidam@yamanashi.ac.jp 
Table S1. Electrochemical specifications of the cathode CLs.

\begin{tabular}{|c|c|c|c|c|c|c|c|}
\hline & \multicolumn{2}{|c|}{ PSS } & \multicolumn{2}{|c|}{ ESP } & \multicolumn{2}{|c|}{ ESN } & \multirow{2}{*}{$\begin{array}{c}\text { Note } \\
-\end{array}$} \\
\hline I/C & 0.3 & 0.7 & 0.3 & 0.7 & 0.3 & 0.7 & \\
\hline $\begin{array}{l}\text { Mass activity } \\
\left(\mathbf{A ~ g}^{-1} \mathbf{P t}\right)\end{array}$ & 76.4 & 101.0 & 71.4 & 103.4 & 105.5 & 200.7 & $\begin{array}{l}\mathrm{H}_{2} / \mathrm{O}_{2} \\
0.85 \mathrm{~V}\end{array}$ \\
\hline$\underset{\left.(\mathrm{mA} \mathrm{cm})^{-2}\right)}{\mathrm{COC}}$ & 1.3 & 1.3 & 0.7 & 0.8 & 1.0 & 1.3 & $\begin{array}{c}\mathrm{H}_{2} / \mathrm{N}_{2} \\
100 \% \mathrm{RH}\end{array}$ \\
\hline \multirow{2}{*}{$\begin{array}{l}\text { Cell voltage } \\
\text { (V) }\end{array}$} & & & 0.245 & 0.488 & 0.375 & 0.516 & $\begin{array}{c}\mathrm{H}_{2} / \mathrm{air} \\
\text { at } 0.6 \mathrm{~A} \mathrm{~cm}^{-2}\end{array}$ \\
\hline & 0.564 & 0.638 & 0.513 & 0.639 & 0.577 & 0.652 & $\begin{array}{c}\mathrm{H}_{2} / \mathrm{O}_{2} \\
\text { at } 0.6 \mathrm{~A} \mathrm{~cm}^{-2}\end{array}$ \\
\hline$\underset{\left(\Omega \mathbf{~ c m}^{2}\right)}{R_{H F}}$ & 0.267 & 0.154 & 0.259 & 0.158 & 0.256 & 0.151 & $\begin{array}{c}\mathrm{H}_{2} / \mathrm{O}_{2} \\
\text { at } 0.6 \mathrm{~A} \mathrm{~cm}^{-2}\end{array}$ \\
\hline $\begin{array}{c}\text { Tafel slope } \\
\left(\text { (mV decade }^{-1}\right)\end{array}$ & 87.8 & 77.4 & 73.3 & 81.2 & 77.5 & 76.6 & $\begin{array}{c}\mathrm{H}_{2} / \mathrm{O}_{2} \\
100 \% \mathrm{RH}\end{array}$ \\
\hline $\begin{array}{c}\text { ECSA } \\
\left(m^{2} g^{-1} \mathbf{P t}\right)\end{array}$ & 24.1 & 36.2 & 23.2 & 36.3 & 25.4 & 43.3 & $\begin{array}{c}70^{\circ} \mathrm{C} \\
100 \% \mathrm{RH}\end{array}$ \\
\hline $\begin{array}{c}C_{\text {dl }} \\
\left(\mathbf{F ~ g}^{-1} \text { catalyst }\right)\end{array}$ & 3.9 & 5.8 & 2.5 & 6.3 & 9.6 & 10.5 & $\begin{array}{l}\text { at } 0.4 \mathrm{~V} \\
\text { from } \mathrm{CV} \\
\text { curve }\end{array}$ \\
\hline $\begin{array}{c}\boldsymbol{\eta}_{\mathbf{t x}\left(\mathbf{o}_{2}, \mathbf{H}^{+}\right), \text {cath }} \\
(\mathbf{m V})\end{array}$ & 156.8 & 145.6 & 295.4 & 71.8 & 175.1 & 84.1 & $\begin{array}{c}\mathrm{H}_{2} / \mathrm{air} \\
\text { at } 0.6 \mathrm{~A} \mathrm{~cm}^{-2}\end{array}$ \\
\hline $\begin{array}{l}\mathbf{R}_{\mathrm{CL}, \mathrm{film}} \\
\left(\mathrm{s} \mathrm{m}^{-1}\right)\end{array}$ & 61.2 & 67.5 & 91.4 & 64.3 & 39.9 & 47.8 & $\begin{array}{c}70^{\circ} \mathrm{C} \\
100 \% \mathrm{RH}\end{array}$ \\
\hline $\begin{array}{c}\sigma_{\mathrm{H}^{+}, \text {cath }} \\
\left(\mathrm{mS} \mathrm{cm}^{-1}\right)\end{array}$ & 0.6 & 1.1 & 0.5 & 1.4 & 0.2 & 1.9 & $\begin{array}{c}70^{\circ} \mathrm{C} \\
100 \% \mathrm{RH}\end{array}$ \\
\hline
\end{tabular}


Slurry viscosities
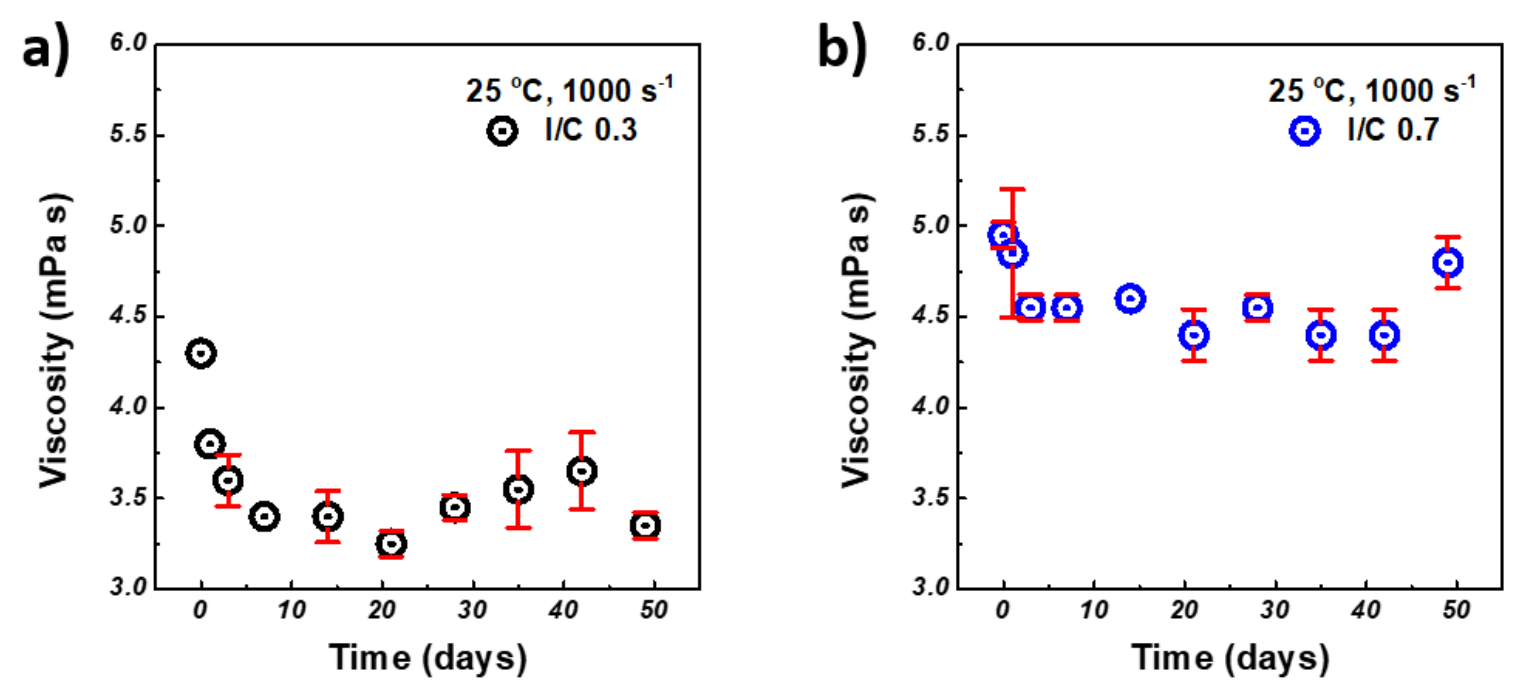

Figure S1. Viscosities of slurries measured at $25{ }^{\circ} \mathrm{C}$ as a function of time (49 days). Each data point is expressed as the mean value \pm S.D. $(n=3)$ : a) $\mathrm{I} / \mathrm{C} 0.3$, b) $\mathrm{I} / \mathrm{C} 0.7$. 


\section{Taylor cone shape}
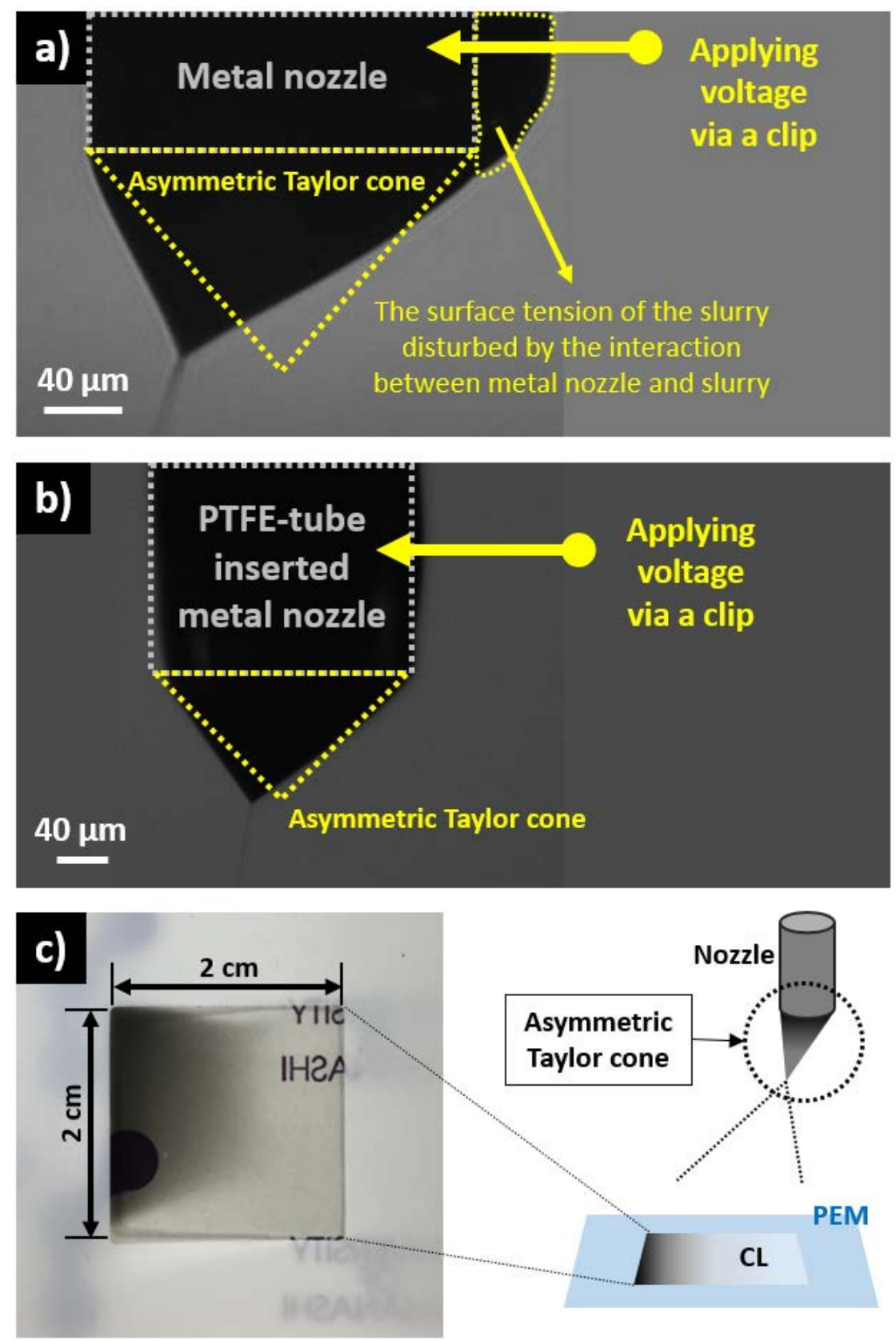

Figure S2. Taylor cone shape dependence on the nozzle construction, with application of voltage by means of a metal clip: a) metal nozzle; b) PTFE-tube inserted metal nozzle; c) CL surface image resulting from the asymmetric Taylor cone of the PTFE-tube inserted metal nozzle. 


\section{Characteristics of the CLs}
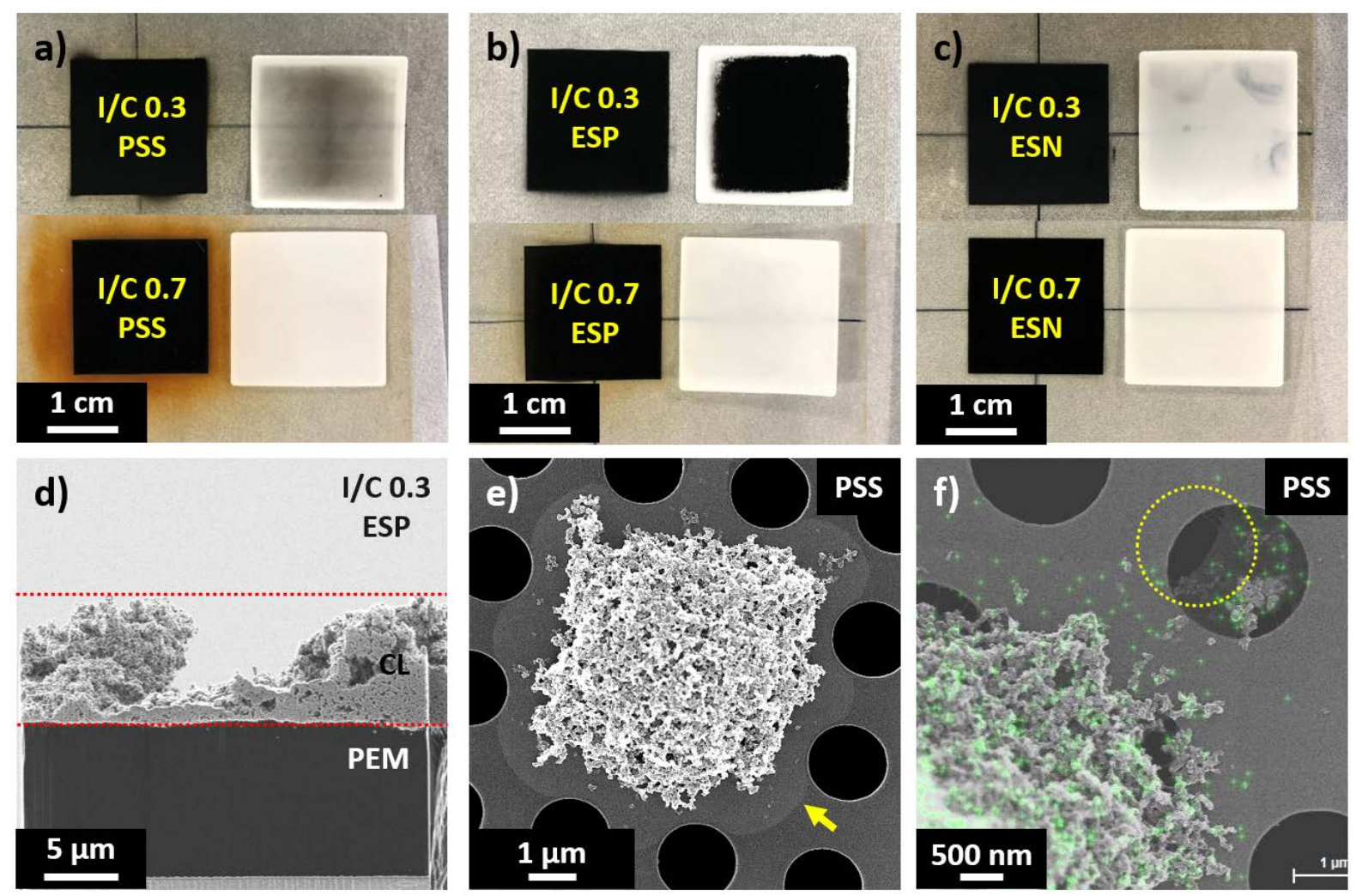

Figure S3. CL images obtained after hot-press processing, with white square representing the PTFE sheet: a, b, c) CLs prepared by PSS, ESP, and ESN, respectively, as a function of ionomer contents; d) cross-sectional image of the CL with I/C 0.3 prepared by ESP after hot-press processing, analyzed by STEM; e) ionomer morphologies generated by PSS, analyzed by STEM; the slurry (ionomer with catalyst) was directly sprayed on the TEM grid; arrows denote an ionomer morphology with catalyst; f) dots represented fluorine in the ionomer, and the dashed-line circle denotes part of the pore of the TEM grid not covered by ionomer. 


\section{Cross-sectional images of the CLs}
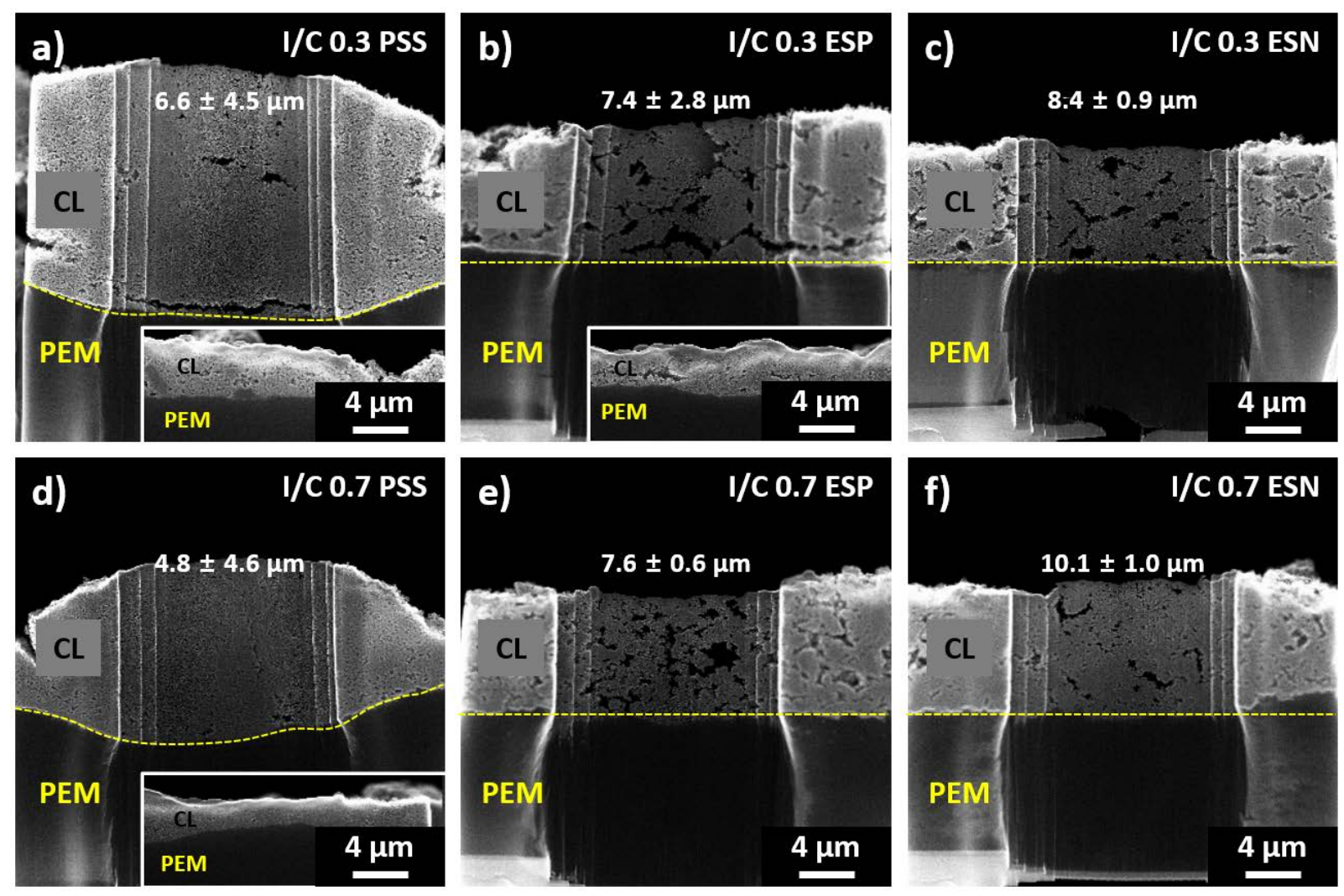

Figure S4. Cross-sectional images of CLs after actual cell performance evaluation, analyzed by STEM, at the same scale; inset images represented a thinner part of the CL of the same MEA: a, d) CLs prepared by PSS, I/C 0.3 and 0.7, respectively; b, e) CLs prepared by ESP, I/C 0.3 and 0.7, respectively; c, f) CLs prepared by ESN, I/C 0.3 and 0.7, respectively.

The CL prepared by PSS showed the most severe thickness deviation compared to other CLs, regardless of ionomer content. In addition, the CL prepared by ESP exhibited a greater thickness deviation for I/C 0.3 than for I/C 0.7, due to the deficiency of the ionomer, which acts as a binder, in addition to the non-uniformity of the distributed ionomer that resulted from positive ionization. 


\section{Surface morphologies of the CLs}
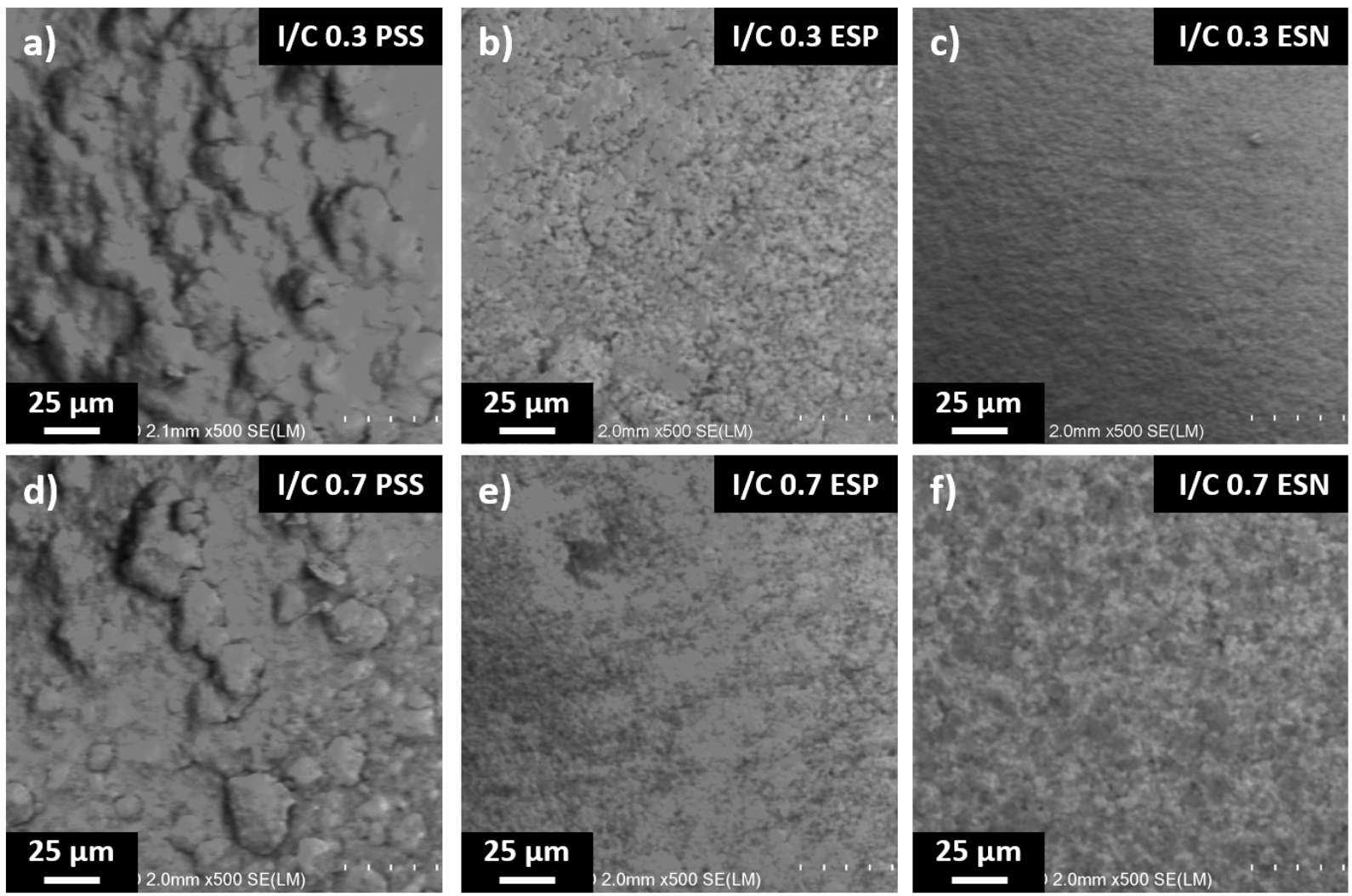

Figure S5. Surface morphologies of CLs after actual cell performance evaluation, analyzed by low-acceleration-voltage (0.3 kV) SEM: a, d) CLs prepared by PSS, I/C 0.3 and 0.7, respectively; b, e) CLs prepared by ESP, I/C 0.3 and 0.7, respectively; c, f) CLs prepared by ESN, I/C 0.3 and 0.7 , respectively. 

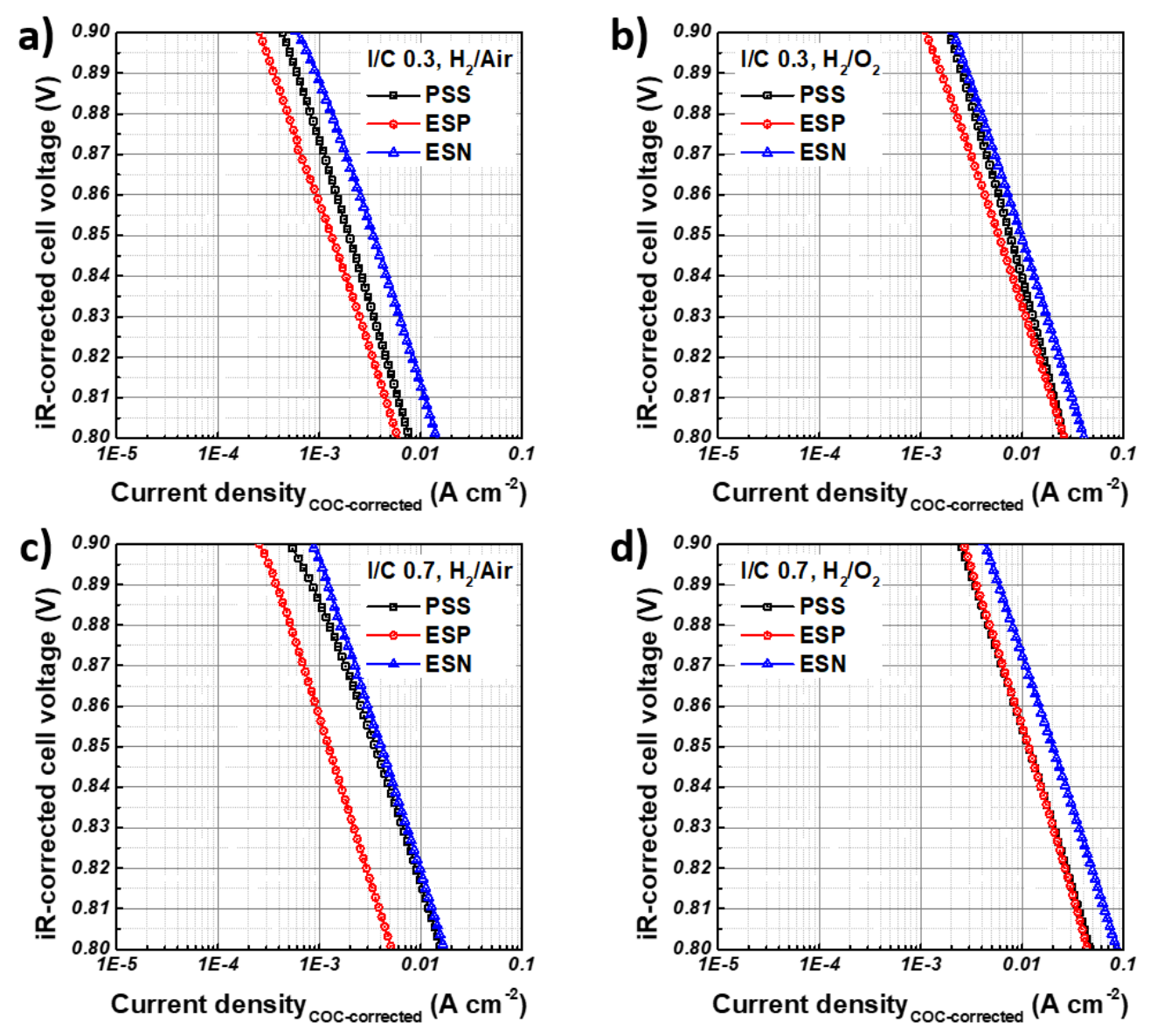

Figure S6. Tafel plots of the CLs at high voltage $(>0.8 \mathrm{~V})$. Polarization curves measured by linear sweep voltammetry (20 mV s${ }^{-1}, 0.8$ to $0.9 \mathrm{~V}$ ) under $\mathrm{H}_{2}$ /air or $\mathrm{O}_{2}$ fixed flow rates (200/100 or 20 sccm), $70{ }^{\circ} \mathrm{C}, 100 \% \mathrm{RH}$, and ambient pressure: a, b) I/C 0.3 air, and $\mathrm{O}_{2}$ operating conditions, respectively: c, d) I/C 0.7 air, and $\mathrm{O}_{2}$ operating conditions, respectively. 

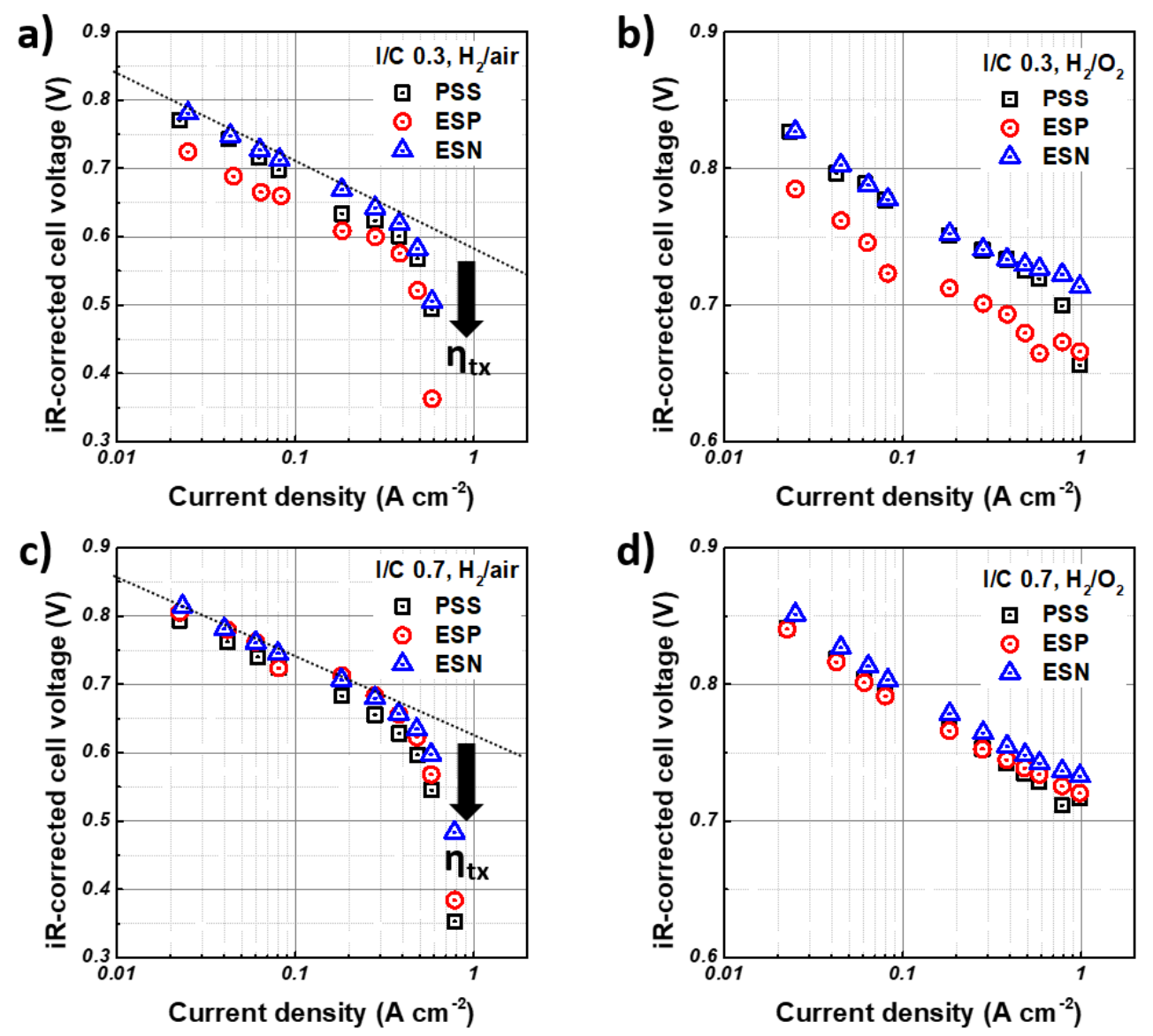

Figure S7. Tafel plots of the CLs. Polarization curves measured by constant current under $\mathrm{H}_{2} / \mathrm{air}$ or $\mathrm{O}_{2}(\lambda=1.4 / 2.5), 70{ }^{\circ} \mathrm{C}, 100 \% \mathrm{RH}$, and ambient pressure: a, b) I/C 0.3 air, and $\mathrm{O}_{2}$ operating conditions, respectively; c, d) I/C 0.7 air, and $\mathrm{O}_{2}$ operating conditions, respectively. 


\section{Cyclic voltammogram curves, ECSA, and $C_{d l}$}
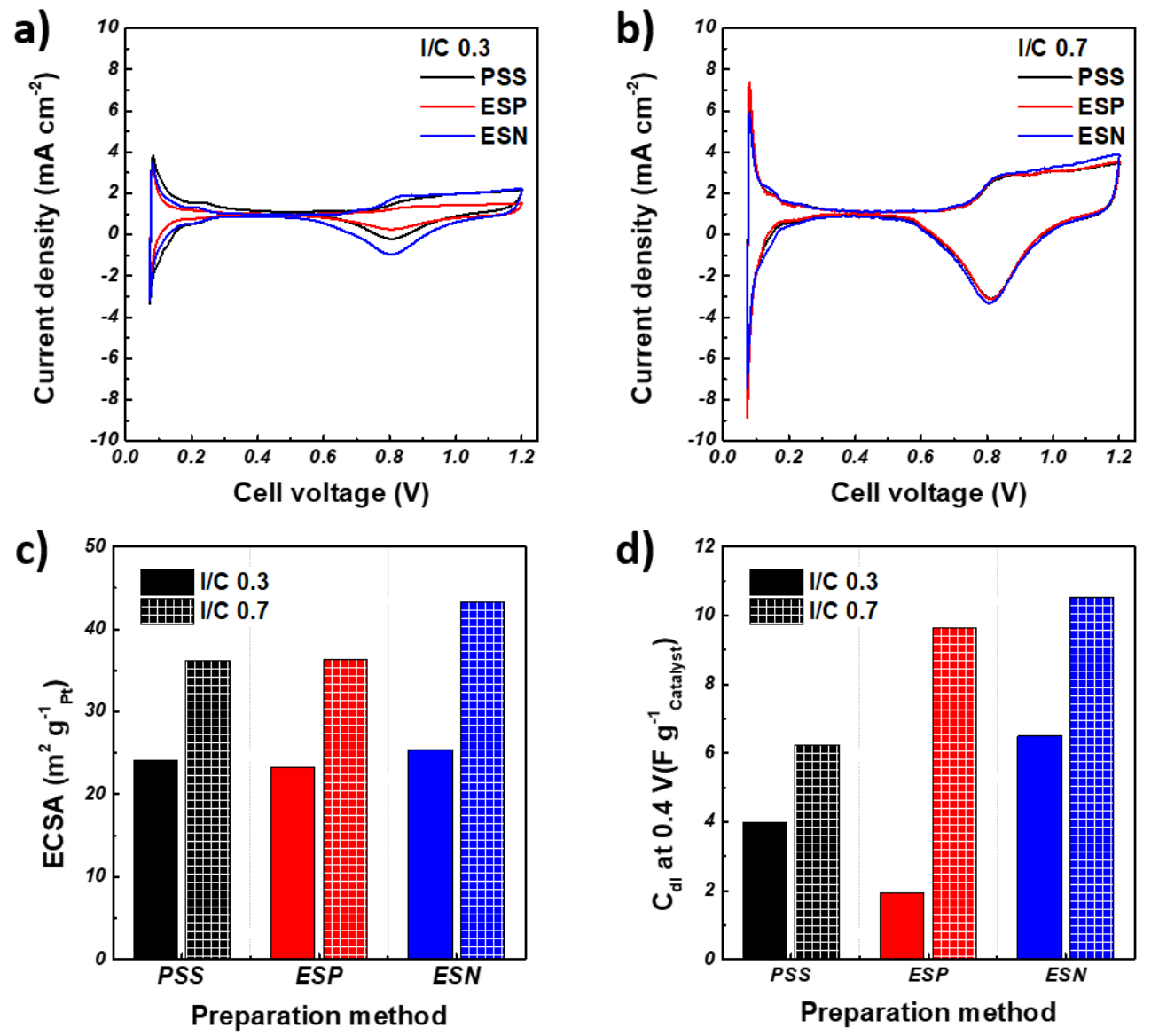

Figure S8. Cyclic voltammograms measured under $70{ }^{\circ} \mathrm{C}, 100 \% \mathrm{RH}$, and without $\mathrm{N}_{2}$ feed on the cathode ( 0.75 to $0.12 \mathrm{~V}, 20 \mathrm{mV} \mathrm{s}^{-1}$ ): a,b) I/C $0.3,0.7$, respectively; c) ECSA of each CL, filled and patterned bars denote I/C 0.3 and 0.7 , respectively; d) $\mathrm{C}_{\mathrm{dl}}$ evaluated at $0.4 \mathrm{~V}$ from the CV curve; filled and patterned bars denote I/C 0.3 and 0.7 , respectively. 


\section{Limiting current and oxygen transport resistance}
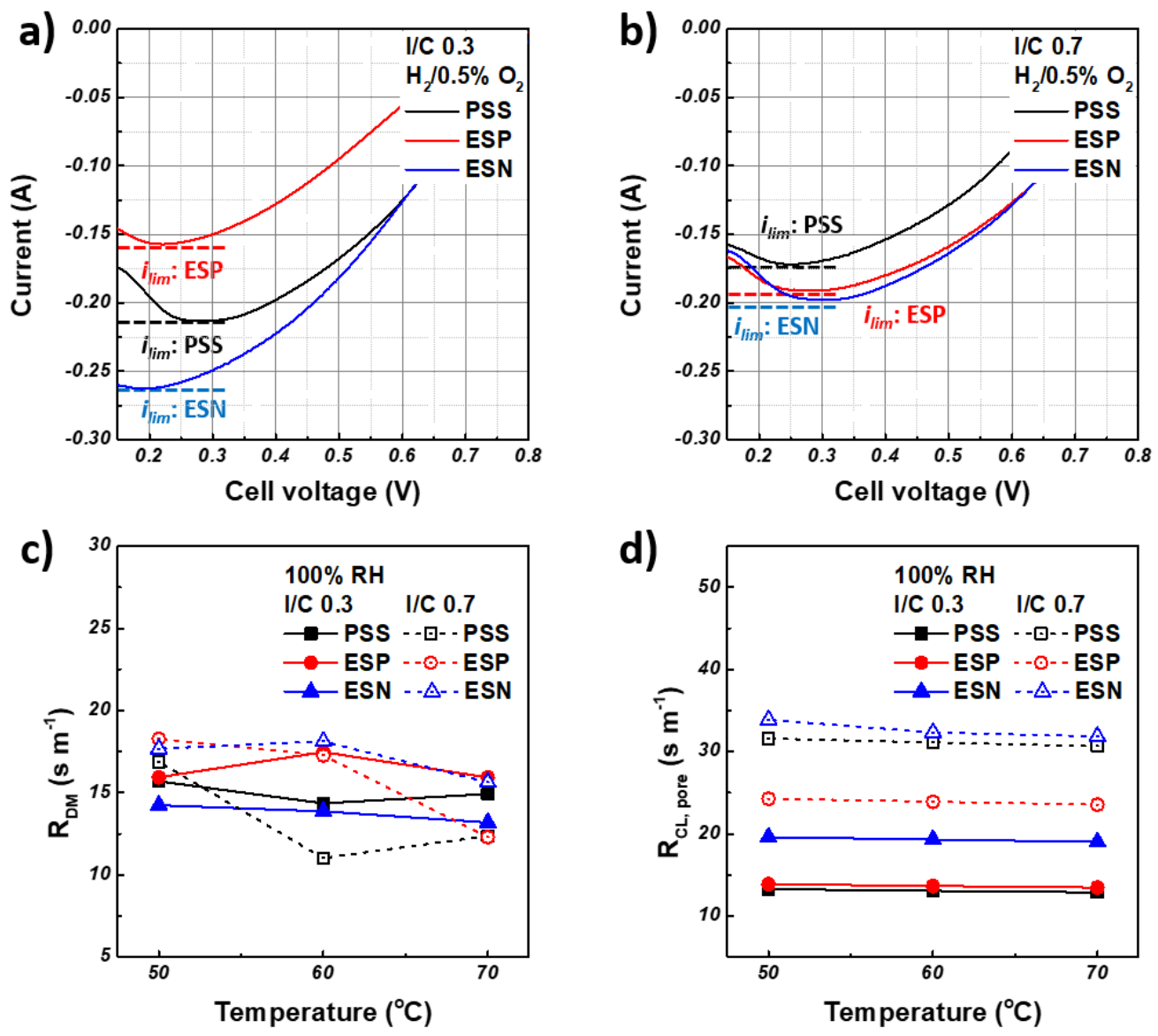

Figure S9. Typical linear sweep curves $\left(10 \mathrm{mV} \mathrm{s}^{-1}, 0.70\right.$ to $\left.0.15 \mathrm{~V}\right)$ of CLs under $\mathrm{H}_{2} / 0.5 \% \mathrm{O}_{2}\left(\mathrm{~N}_{2}\right.$ balance), $70{ }^{\circ} \mathrm{C}, 100 \% \mathrm{RH}$, and ambient pressure: a,b) I/C 0.3 and I/C 0.7, respectively; oxygen transport resistance in the cathode evaluated by limiting current measurement as a function of temperature, linear sweep voltammetry under $\mathrm{H}_{2} / 0.5 \% \mathrm{O}_{2}\left(\mathrm{~N}_{2}\right.$ or He balance) and $100 \% \mathrm{RH}$ operating conditions; solid and dashed lines denote I/C 0.3 and 0.7 , respectively; c) $R_{D M}$; d) $R_{C L, \text { pore }}$. 

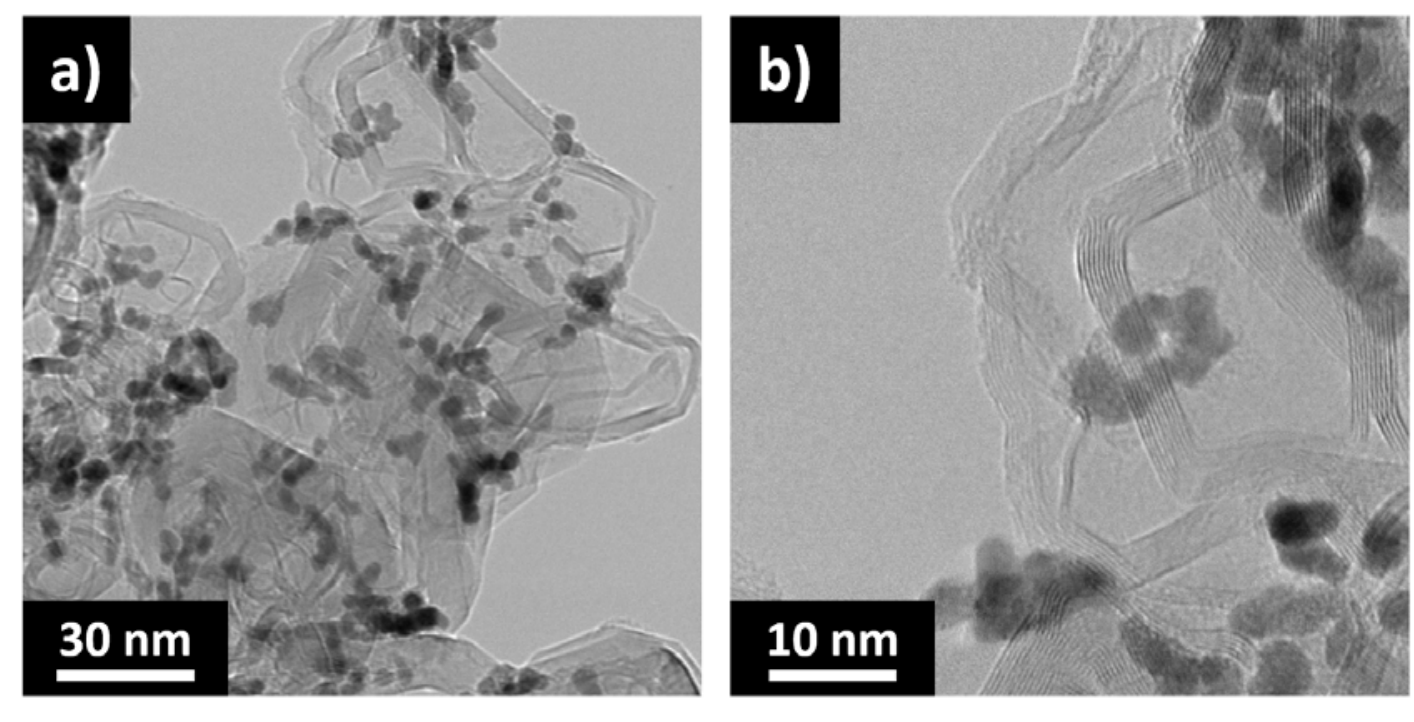

Figure S10. TEM images of the catalyst (TEC10EA30E) with different magnifications. a) $\times 200$ k. b) $\times 500 \mathrm{k}$. 
Table S2. Mass activity at $0.85 \mathrm{~V}, \mathrm{H}_{2} /$ air, $\mathrm{I} / \mathrm{C} 0.7$ conditions

\begin{tabular}{|c|c|c|c|}
\hline & Takahashi et al. ${ }^{1}$ & Park et al. ${ }^{2}$ & This study \\
\hline $\begin{array}{l}\text { Mass activity } \\
\qquad\left(\mathrm{A} \mathrm{g}^{-1} \mathbf{P t}\right)\end{array}$ & 19 & 48 & 32 \\
\hline $\begin{array}{l}\text { Cell temperature } \\
\qquad\left({ }^{\circ} \mathrm{C}\right)\end{array}$ & 80 & 80 & 70 \\
\hline
\end{tabular}

\section{REFERENCES}

1. Takahashi, K.; Kakinuma, K.; Uchida, M. Improvement of Cell Performance in Low-Pt-L oading PEFC Cathode Catalyst Layers Prepared by the Electrospray Method. J. Electroch em. Soc. 2016, 163 (10), F1182-F1188.

2. Park, Y. C.; Tokiwa, H.; Kakinuma, K.; Watanabe, M.; Uchida, M. Effects of carbon supp orts on Pt distribution, ionomer coverage and cathode performance for polymer electrolyt e fuel cells. J. Power Sources 2016, 315, 179-191. 